\title{
Study Further Information Contact
}

National Cancer Institute

\section{Source}

National Cancer Institute. Study Further Information Contact. NCI Thesaurus. Code C127530.

The contact person responsible for disseminating additional information about a study. 